\title{
Genetics of Ankylosing Spondylitis
}

\author{
ALAN E. H. EMERY and JOHN S. LAWRENCE \\ From the Manchester University Department of Medical Genetics, The Royal Infirmary, Manchester 13, \\ and the A.R.C. Field Unit, Clinical Sciences Building, Manchester 13
}

Ankylosing spondylitis, also sometimes referred to as rheumatoid spondylitis or Marie-Strumpell disease, is a chronic arthritis affecting the small joints of the spine, sacro-iliac joints, occasionally the peripheral joints (shoulders, hips, and knees), and sometimes the costovertebral, sternoclavicular, and costosternal joints. The onset is usually before the age of 30. At first the affected joints are painful and there is limitation of joint movement but after several years there is painless ankylosis. The disease is compatible with normal survival except in the small proportion of patients who develop aortic incompetence.

Ankylosing spondylitis occurs in Caucasian populations with a frequency of around 2 per 1000 and is commoner in males than in females (Lawrence, 1963). Summarizing the results of several previously reported studies of the frequency of the disease in relatives, Kellgren (1964) estimated a mean prevalence of $0 \cdot 1-0 \cdot 2 \%$ in controls and $4 \%$ in relatives. Ankylosing spondylitis is therefore much commoner among the relatives of affected subjects than in the general population.

Previous studies, which were based on the familial incidence of overt clinical disease, have suggested that this condition is due to an autosomal dominant gene (Hersh, Stecher, Solomon, Wolpaw, and Hauser, 1950; Stecher and Hersh, 1955; Stecher, 1957; Blécourt, Polman, and Blécourt-Meindersma, 1961; Karten, DiTata, McEwen, and Tanner, 1962). This explanation, however, seems rather unsatisfactory because only about $4 \%$ of firstdegree relatives have clinical manifestations of spondylitis.

Sacro-iliitis is present in almost all patients with clinical manifestations of ankylosing spondylitis (Scott, 1942). It is one of the earliest manifestations of the disease and is often symptomless (Gofton, Lawrence, Bennett, and Burch, 1966) and only recognizable on $x$-ray film. In the present investigation the familial incidence of radiographic evidence of sacro-iliitis, with or without other mani-

Received April 5, 1967. festations of ankylosing spondylitis, has been studied. The results suggest that it may be multigenic in causation.

\section{Subjects and Methods}

Probands. The probands were patients with ankylosing spondylitis who attended the Christie Hospital in Manchester for radiotherapy during the period 1957-1959 and who lived within 15 miles of the centre of Manchester. Altogether there were 76 probands (63 males and 13 females). Details are given in an Appendix.

Relatives. All first-degree relatives over age 14 who lived in the U.K. were sought. Altogether there were 484 first-degree relatives but only 274 were accessible to study, the remainder being under age, dead, or not traceable. Of the 274 accessible relatives, 250 (133 males, 117 females) co-operated and were investigated. The completion rate was therefore $92 \%$ (Bremner, Emery, Kellgren, Lawrence, and Roth, 1967).

Those relatives who co-operated underwent a thorough clinical examination of the musculo-skeletal system and $x$-ray pictures of the sacro-iliac joints were taken in males over 14 years and in females over 44 years. The combined results of 8 surveys from various parts of the world, involving 1750 subjects (from 15 to $65+$ ), indicate that the incidence of sacro-iliitis in the general population is not affected by age (Gofton et al., 1966).

Controls. A population survey was carried out on an area sample in Watford near London. Subjects in the same age range as the probands and their relatives were examined clinically and had $x$-ray films taken of the sacro-iliac joints. This gave us 188 controls (122 males and 66 females). Details of this survey have been published previously (Ansell and Lawrence, 1966).

Criteria Used in Diagnosing Ankylosing Spondylitis. Two diagnostic categories have been used.

A. 'Clinical ankylosing spondylitis', as diagnosed on the clinical findings at the time of the survey.

B. 'Sacro-iliitis', in which there was $x$-ray evidence of bilateral sacro-iliitis of the type encountered in ankylosing spondylitis.

Interpretation of Pelvic $X$-ray Pictures. All $x$-ray films were read blind by two observers and those 
in which there was disagreement were re-read to give a reconciled grading. The young males were read a third time in order to reduce the probability of misinterpretation due to unfused epiphyses. Only definite and unequivocal involvement of both sacro-iliac joints, in accordance with grades $2-4$ in the Atlas of Standard Radiographs of Arthritis (C.I.O.M.S., 1963), was accepted as evidence of sacro-iliitis.

\section{Results}

A total of 76 families has been studied; in 29 of these there was more than one affected person with sacro-iliitis with or without other manifestations of ankylosing spondylitis. There were 50 spouses (8 men and 42 women) of affected subjects, but none had sacro-iliitis with or without other manifestations of ankylosing spondylitis. Among the firstdegree relatives there were two pairs of nonidentical twins: female twins age $\mathbf{4 2}$ neither of whom had spondylitis, and male twins age 16 both with sacro-iliitis.

In calculating the proportion of affected relatives the proband has been omitted from each family (Fisher, 1934). Two male probands were related: a man of 54 was the paternal uncle of a man aged 24. This family was counted twice omitting the proband each time. The proportion of first-degree relatives with clinical ankylosing spondylitis is given in Table I and the results are in good agreement with those of previous studies (reviewed by Kellgren, 1964).

In order to study the mode of inheritance it is necessary to determine the proportions of affected parents, sibs, and offspring separately. This is impracticable when considering clinical ankylosing spondylitis because so few relatives are affected. However, the number of first-degree relatives with sacro-iliitis, with or without other manifestations of spondylitis, is greater and therefore more amenable to analysis (Table I). The proportions of various relatives affected in this way were as follows: 4 out of 24 fathers ( $16.67 \%), 0$ of 30 mothers, 13 out of 82 brothers $(15 \cdot 85 \%), 5$ out of 30 sisters $(16 \cdot 67 \%)$, and 8 out of 22 sons $(36.36 \%)$. The proportion of affected sons was significantly greater than the proportion of affected brothers and fathers. This may be due partly to the misinterpretation of the pelvic $x$-ray pictures in some of the younger males. Autosomal recessive inheritance seems unlikely because the proportion of affected sibs is no greater than the proportion of other affected relatives. If only the data for brothers are considered, and these are the most complete, if ankylosing spondylitis is due to an autosomal dominant gene then penetrance would only be about $32 \%$. If it were an X-linked trait, since it is a fairly common disease, occasionally apparent male-to-male transmission might occur because an affected male happened to marry a carrier female. In the present study, in 11 out of 29 families there were instances of male-to-male transmission, which is far more frequent than would be expected even for a common X-linked condition. $\mathrm{X}$-linkage therefore seems unlikely. The possibility remains that the disease is at least partly multigenic in causation.

If a particular trait is due to the cumulative effects of many genes, then a threshold effect may make the distribution of liability appear discontinuous, i.e. so-called quasi-continuous (Grüneberg, 1952). It has been shown that in quasi-continuous variation, if the incidence of a particular trait in the general population is $p$ then the expected incidence in firstdegree relatives of probands is approximately $\sqrt{ } p$ (Edwards, 1960, 1963). The relevant calculations in the present study are given in Table II. There was fairly good agreement between the expected and observed proportions of affected relatives, though the observed proportions were slightly less than the expected values. This is possibly because the expected proportions $(\sqrt{ } p)$ are based on the assump-

TABLE I

PROPORTION OF CONTROLS AND FIRST-DEGREE RELATIVES OF PROBANDS, WITH (1) CLINICAL ANKYLOSING SPONDYLITIS, (2) BILATERAL SACRO-ILIITIS WITH OR WITHOUT OTHER MANIFESTATIONS OF ANKYLOSING SPONDYLITIS

\begin{tabular}{|c|c|c|c|c|c|c|c|c|c|c|c|}
\hline & & \multirow{2}{*}{ Age } & \multicolumn{3}{|c|}{ Males } & \multicolumn{3}{|c|}{ Females } & \multicolumn{3}{|c|}{ Total } \\
\hline & & & Total & Affected & $\begin{array}{c}\% \\
\text { Affected }\end{array}$ & Total & Affected & $\begin{array}{c}\% \\
\text { Affected }\end{array}$ & Total & Affected & $\begin{array}{c}\% \\
\text { Affected }\end{array}$ \\
\hline $\begin{array}{l}\text { (1) } \\
\text { (2) }\end{array}$ & $\begin{array}{l}\text { Clinical ankylosing spondylitis } \\
\text { Controls* } \\
\text { Relatives } \\
\text { Bilateral sacro-iliitist }\end{array}$ & $\begin{array}{l}15+ \\
15+ \\
30+\end{array}$ & $\begin{array}{r}1060 \\
133 \\
100\end{array}$ & $\begin{array}{l}4 \\
7 \\
7\end{array}$ & $\begin{array}{l}0.38 \\
5 \cdot 26 \\
7.00\end{array}$ & $\begin{array}{r}1173 \\
117 \\
94\end{array}$ & $\begin{array}{l}0 \\
2 \\
2\end{array}$ & $\begin{array}{l}0 \\
1 \cdot 71 \\
2 \cdot 13\end{array}$ & $\begin{array}{r}2233 \\
250 \\
194\end{array}$ & $\begin{array}{l}4 \\
9 \\
9\end{array}$ & $\begin{array}{l}0 \cdot 18 \\
3 \cdot 60 \\
4 \cdot 64\end{array}$ \\
\hline & $\begin{array}{l}\text { Controls } \\
\text { Relatives }\end{array}$ & $\bar{z}$ & $\begin{array}{l}122 \\
128\end{array}$ & $\begin{array}{r}6 \\
25\end{array}$ & $\begin{array}{r}4.92 \\
19.53\end{array}$ & $\begin{array}{l}66 \\
60\end{array}$ & $\frac{1}{5}$ & $\begin{array}{l}1 \cdot 52 \\
8 \cdot 33\end{array}$ & $\begin{array}{l}188 \\
188\end{array}$ & $\begin{array}{r}7 \\
30\end{array}$ & $\begin{array}{r}3 \cdot 72 \\
15.96\end{array}$ \\
\hline
\end{tabular}

* Data from Lawrence (1963).

† Males over 14 years, females over 44 years. 
TABLE II

INCIDENCE IN GENERAL POPULATION AND IN FIRST-DEGREE RELATIVES OF PROBANDS, OF SACROILIITIS WITH OR WITHOUT OTHER MANIFESTATIONS OF ANKYLOSING SPONDYLITIS

\begin{tabular}{|c|c|c|c|c|c|c|c|}
\hline & \multirow{2}{*}{\multicolumn{3}{|c|}{ General Population }} & \multicolumn{4}{|c|}{ Proportion of Affected Relatives } \\
\hline & & & & \multirow{2}{*}{$\begin{array}{c}\text { Expected } \\
\qquad \sqrt{ } \mathbf{p} \% \\
\end{array}$} & \multicolumn{3}{|c|}{ Observed } \\
\hline & Total & Affected & Incidence & & Total & Affected & $\%$ Affected \\
\hline $\begin{array}{l}\text { Males } \\
\text { Females }\end{array}$ & $\begin{array}{r}122 \\
66\end{array}$ & $\begin{array}{l}6 \\
1\end{array}$ & $\begin{array}{l}0.04918 \\
0.01515\end{array}$ & $\begin{array}{l}22 \cdot 18 \\
12 \cdot 31\end{array}$ & $\begin{array}{r}128 \\
60\end{array}$ & $\begin{array}{r}25 \\
5\end{array}$ & $\begin{array}{r}19 \cdot 53 \\
8 \cdot 33\end{array}$ \\
\hline
\end{tabular}

tion that there is complete genetic determination, i.e. a maximal value for multifactorial inheritance.

The relative incidence (Penrose, 1953) in male and female sibs (for each sex the incidence in sibs divided by the incidence in the general population) has been calculated assuming different modes of inheritance (Edwards, 1960). Again agreement is best when multifactorial inheritance is assumed (Table III).

TABLE III

RELATIVE INCIDENCE IN SIBS OF SACRO-ILIITIS WITH OR WITHOUT OTHER MANIFESTATIONS OF ANKYLOSING SPONDYLITIS

\begin{tabular}{|c|c|c|c|c|c|}
\hline & \multirow[b]{2}{*}{$\begin{array}{l}\text { Incidence } \\
\text { in General } \\
\text { Population }\end{array}$} & \multirow[b]{2}{*}{\begin{tabular}{|} 
Observed \\
Relative \\
Inci- \\
dence \\
in Sibs \\
\end{tabular}} & \multicolumn{3}{|c|}{$\begin{array}{l}\text { Expected Relative Incidence } \\
\text { in Sibs }\end{array}$} \\
\hline & & & $\underset{\left(\frac{1}{2} p^{-1}\right)}{\operatorname{Dominant}}$ & $\underset{\left(4 \mathbf{p}^{-1}\right)}{\text { Recessive }}$ & $\begin{array}{c}\text { Multi- } \\
\text { factorial } \\
\left(\mathbf{p}^{-1 / 2}\right)\end{array}$ \\
\hline $\begin{array}{l}\text { Iales } \\
\text { emales }\end{array}$ & $\begin{array}{l}0.04918 \\
0.01515\end{array}$ & $\begin{array}{r}3.22 \\
11.00\end{array}$ & $\begin{array}{l}10 \cdot 17 \\
33.00\end{array}$ & $\begin{array}{r}5 \cdot 08 \\
16 \cdot 50\end{array}$ & $\begin{array}{l}4 \cdot 51 \\
8 \cdot 12\end{array}$ \\
\hline
\end{tabular}

For diseases in which the genetic predisposition is multifactorial, Falconer (1965) has derived formulae for calculating the heritability, which is the proportion of the total phenotypic variance due to additive genetic variance. In the present study 7 out of 188 controls compared with 30 out of 188 first-degree relatives had bilateral sacro-iliitis with or without other manifestations of ankylosing spondylitis. From these data the heritability of the liability to sacro-iliitis with or without other manifestations of spondylitis is $72.5 \pm 10.2 \%$ (weighted mean). It was not possible to make meaningful comparisons between like-sexed and unlike-sexed relatives because of the wide limits of the sampling errors due to the small sample sizes. With regard to clinical ankylosing spondylitis, 4 out of 2233 controls were affected compared with 9 out of 250 first-degree relatives (Table I). From these data the heritability of the liability to clinical ankylosing spondylitis is $70 \cdot 0 \pm 9 \cdot 3 \%$.

\section{Discussion}

Evidence from several sources suggests that ankylosing spondylitis is hereditary. The inci- dence in first-degree relatives of affected subjects is some 20 times greater than in the general population, and of the 10 pairs of monozygotic twins recorded in the literature, where one twin had the condition in 7 instances the other twin was also affected (Moesmann, 1960; Julkunen, 1962). Regarding the mode of inheritance, several investigators have suggested that it is due to an autosomal dominant gene (West, 1949; Hersh et al., 1950; Stecher and Hersh, 1955; Stecher, 1957; O’Connell, 1959; Blécourt et al., 1961; Karten et al., 1962). However, families in which the disease is clearly inherited as an autosomal dominant trait through several generations are rare (Riecker, Neel, and Test, 1950; Graham and Uchida, 1957), and it has therefore been assumed that the gene is not always fully penetrant. Assuming that it is due to an autosomal dominant gene it has been estimated that the gene is penetrant (produces the full clinical picture) in $70-80 \%$ of males but only in about $10 \%$ of females (Hersh et al., 1950; Stecher and Hersh, 1955; Karten et al., 1962). Incomplete penetrance as an explanation for pedigree patterns in common disorders is rather unsatisfactory for a number of reasons, and becomes rather meaningless when a very low penetrance has to be assumed (Edwards, 1960). Further, in arriving at their estimates of penetrance, Hersh et al. (1950) and Karten et al. (1962) assumed complete ascertainment of cases basing their calculations for the expected number of affected subjects on a truncated binomial (Hogben, 1932, 1946). This method of analysis assumes that every family with at least one affected person is equally certain to be ascertained. However, this is only possible when a defined population has been exhaustively examined (Crow, 1965), and in studies based on the presentation of cases at a hospital, as in the studies of Hersh et al. (1950) and Karten et al. (1962), this is not true. In the present investigation incomplete ascertainment has been assumed and the proportion of affected individuals determined by omitting the proband from each family.

It was impossible to obtain a clear idea of the mode of inheritance of ankylosing spondylitis from 
the proportion of parents, sibs, and offspring with the clinical form because so few relatives were affected. However, the number of first-degree relatives with sacro-iliitis, with or without other manifestations of ankylosing spondylitis, was much greater and therefore more amenable to analysis. The proportions of parents, sibs, and offspring, with sacro-iliitis appeared to fit no simple mode of inheritance. However, the proportion of affected first-degree relatives agreed fairly well with the proportion expected $(\sqrt{ } p)$ on multifactorial inheritance and the relative incidence in male and female sibs also agreed best when multifactorial inheritance was assumed. If ankylosing spondylitis is multigenic in causation, estimates of the heritability may be obtained, heritability being that proportion of the total phenotypic variance which is due to additive genetic variance. The estimate of heritability based on the data for sacro-iliitis with or without other manifestations of spondylitis $(72.5 \pm$ $10.2 \%$ ) was in fairly good agreement with the estimate based on the data for clinical ankylosing spondylitis $(70.0 \pm 9.3 \%)$. Estimates of heritability however are only valid if there is no major gene contributing to the cause of the disease, since this would lead to discontinuity in the distribution of liability. If the condition were due to a dominant gene, then estimates of heritability would be unreasonably high (Falconer, 1965). The estimates of heritability obtained in the present study were not abnormally high. Another important factor to be considered is that relatives may resemble each other because of non-genetic causes, i.e. exposure to the same environmental factors. This is particularly so in the case of sibs, the correlation between whom is also contributed to by non-additive genetic variance (Falconer, 1965). Errors due to environmental causes of resemblance would be much less in second- and third-degree relatives than in firstdegree relatives. The incidence of sacro-iliitis in second- and third-degree relatives is being investigated.

An important problem posed by the present investigation is why only a proportion of subjects with radiographic evidence of sacro-iliitis apparently go on to develop the full clinical picture of ankylosing spondylitis. An answer to this question could provide a therapeutic or even a prophylactic approach to ankylosing spondylitis.

\section{Summary}

Previous studies, based on the familial incidence of overt clinical disease, have suggested that ankylosing spondylitis is due to an autosomal dominant gene. This hypothesis seems rather unsatisfactory because penetrance would have to be very low to account for the fact that only about $4 \%$ of firstdegree relatives are affected with the clinical form.

In the present investigation the familial incidence of radiographic evidence of bilateral sacro-iliitis, with or without other manifestations of ankylosing spondylitis, has been studied in 188 first-degree relatives of 76 patients with spondylitis. Of firstdegree relatives, $16 \%$ were found to be affected compared with $3.7 \%$ of controls. Evidence is presented which suggests that it is multigenic in causation. The heritability of the liability to the disease based on the incidence of clinical disease in relatives and controls was estimated to be $70.0 \pm$ $9.3 \%$ and when based on the incidence of sacroiliitis, with or without other manifestations of ankylosing spondylitis, to be $72 \cdot 5 \pm 10 \cdot 2 \%$.

We are grateful to Dr. D. S. Falconer for reading the manuscript and for making several very helpful suggestions.

\section{REFERENCES}

Ansell, B. M., and Lawrence, J. S. (1966). Fluoridation and the rheumatic diseases. A comparison of rheumatism in Watford and Leigh. Ann. rheum. Dis., 25, 67.

Blécourt, J. J. de, Polman, A., and Blécourt-Meindersma, T. de (1961). Hereditary factors in rheumatoid arthritis and ankylosing spondylitis. ibid., 20, 215.

Bremner, J. M., Emery, A. E. H., Kellgren, J. H., Lawrence, J. S., and Roth, H. (1967). A family study in ankylosing spondylitis. In Population Studies of the Rheumatic Diseases. Proc. III Internat. Symp., ed. P. H. Bennett and P. H. N. Wood, chapter 40. (Internat. Congr. Ser. 148.) Excerpta Medica, Amsterdam.

C.I.O.M.S. (1963). The Epidemiology of Chronic Rheumatism, Vol. 2, Atlas of Standard Radiographs of Arthritis. Blackwell, Oxford.

Crow, J. F. (1965). Problems of ascertainment in the analysis of family data. In Genetics and the Epidemiology of Chronic Diseases, ed. J. V. Neel, M. W. Shaw, and W. J. Schull, p. 23. U.S. Dept. of Health, Washington, D.C.

Edwards, J. H. (1960). The simulation of Mendelism. Acta genet. (Basel), 10, 63.

(1963). The genetic basis of common disease. Amer. F. Med. 34,627 .

Falconer, D. S. (1965). The inheritance of liability to certain diseases estimated from the incidence among relatives. Ann. hum. Genet., 29, 51.

Fisher, R. A. (1934). The effects of methods of ascertainment upon the estimation of frequencies. Ann. Eugen. (Lond.), 6, 13.

Gofton, J. P., Lawrence, J. S., Bennett, P. H., and Burch, T. A. (1966). Sacro-iliitis in eight populations. Ann. rheum. Dis., 25, 528.

Graham, W., and Uchida, I. A. (1957). Heredity in ankylosing spondylitis. ibid., 16, 334 .

Grüneberg, H. (1952). Genetical studies on the skeleton of the mouse. IV. Quasi-continuous variations. F. Genet., 51, 95.

Hersh, A. H., Stecher, R. M., Solomon, W. M., Wolpaw, R., and Hauser, H. (1950). Heredity in ankylosing spondylitis, a study of 50 families. Amer. F. hum. Genet., 2, 391.

Hogben, L. (1932). The genetic analysis of familial traits. II Double gene substitutions, with special reference to hereditary dwarfism. F. Genet., 25, 211.

(1946). An Introduction to Mathematical Genetics. Norton, New York.

Julkunen, H. (1962). Rheumatoid spondylitis: clinical and laboratory study of 149 cases compared with 182 cases of rheumatoid arthritis. Acta rheum. scand., Suppl. 4.

Karten, I., DiTata, D., McEwen, C., and Tanner, M. (1962). A family study of rheumatoid (ankylosing) spondylitis. Arthr. and Rheum., 5, 131. 
Kellgren, J. H. (1964). Heberden oration, 1963. The epidemiology of rheumatic diseases. Ann. rheum. Dis., 23, 109.

Lawrence, J. S. (1963). The prevalence of arthritis. Brit. F. clin. Pract., 17, 699.

Moesmann, G. (1960). Hereditary and exogenous etiological factors in ankylosing spondylitis. Ankylosing spondylitis in two sets of monozygotic twins. Acta rheum. scand., 6, 144.

O'Connell, D. (1959). Heredity in ankylosing spondylitis. Ann. intern. Med., 50, 1115.

Penrose, L. S. (1953). The genetical background of common diseases. Acta genet. (Basel), 4, 257.
Riecker, H. H., Neel, J. V., and Test, A. (1950). The inheritance of spondylitis rhizomelique (ankylosing spondylitis) in the K. family Ann. intern. Med., 33, 1254.

Scott, S. G. (1942). A Monograph on Adolescent Spondylitis or Ankylosing Spondylitis. Oxford University Press, London.

Stecher, R. M. (1957). Heredity in joint diseases. Docum. rheum. Geigy, 12.

- , and Hersh, A. H. (1955). Familial occurrence of ankylosing spondylitis. Brit. $\mathcal{F}$. phys. Med., 18, 176.

West, H. F. (1949). The aetiology of ankylosing spondylitis. Ann. rheum. Dis., 8, 143.

\section{Appendix}

\section{Details of Families Studied}

Numbers refer to age at the time of examination. Radiographic findings are indicated as $\mathbf{N}$ (normal), $\mathrm{A}$ (abnormal), - (not known); clinical findings as $\mathrm{n}$ (normal), a (affected), or - (not known). For each individual the radiographic findings are given before the clinical findings.

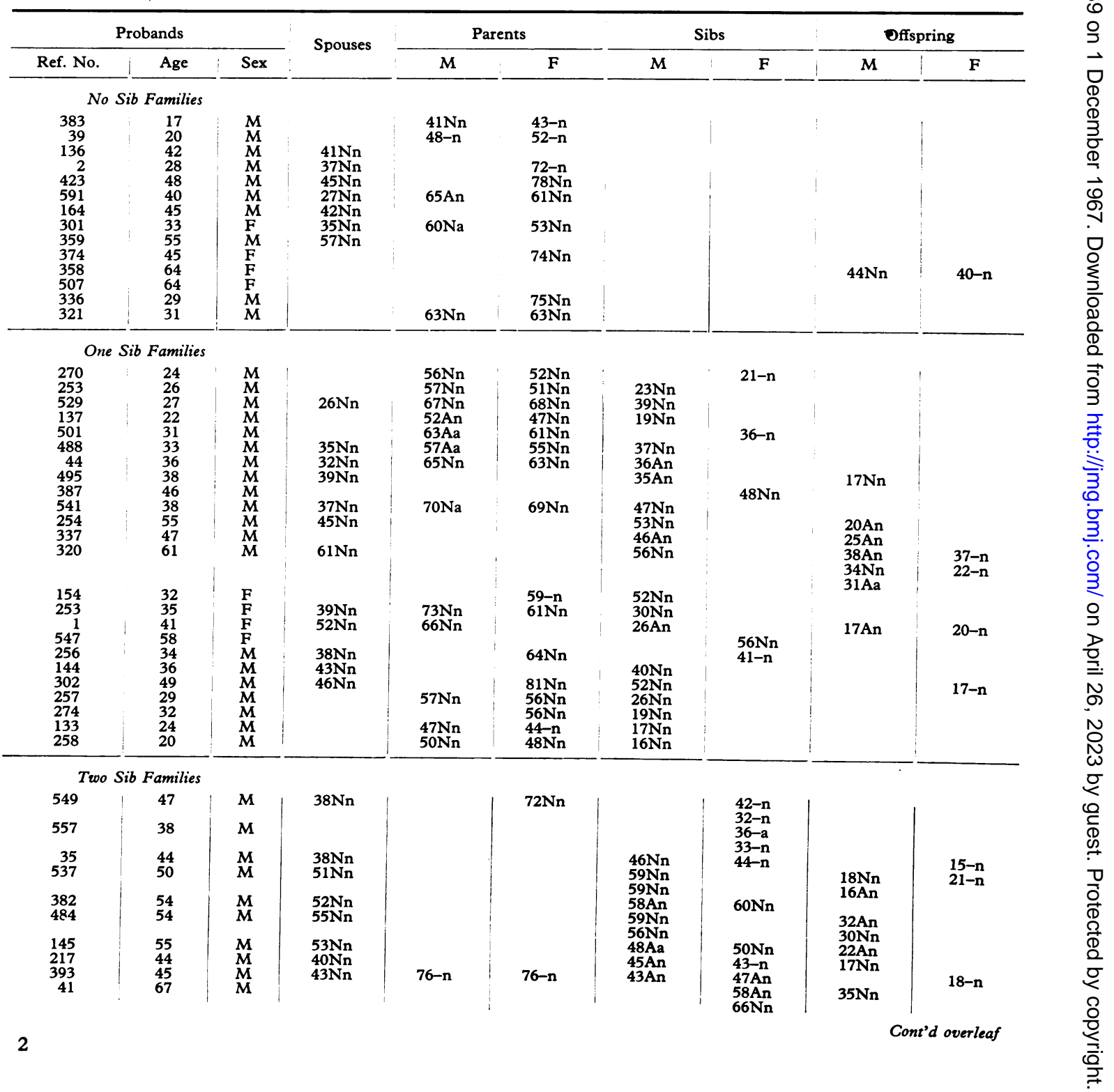




\begin{tabular}{|c|c|c|c|c|c|c|c|c|c|}
\hline \multicolumn{3}{|c|}{ Probands } & \multirow{2}{*}{ Spouses } & \multicolumn{2}{|c|}{ Parents } & \multicolumn{2}{|c|}{ Sibs } & \multicolumn{2}{|c|}{ Offspring } \\
\hline Ref. No. & Age & Sex & & $\mathbf{M}$ & $\mathrm{F}$ & $M$ & $F$ & $M$ & $F$ \\
\hline \multicolumn{10}{|c|}{ Two Sib Families Cont'd } \\
\hline $\begin{array}{r}50 \\
500\end{array}$ & $\begin{array}{l}32 \\
60\end{array}$ & $\underset{\mathbf{M}}{\mathbf{M}}$ & $\begin{array}{l}\text { 29Nn } \\
\text { 57Nn }\end{array}$ & $58 \mathrm{Nn}$ & $57 \mathrm{Nn}$ & $\begin{array}{l}30 \mathrm{An} \\
55 \mathrm{Nn}\end{array}$ & $21-\mathrm{n}$ & \multirow{3}{*}{$19 \mathrm{Nn}$} & \multirow{6}{*}{$\begin{array}{l}15-n \\
27-n \\
19-n\end{array}$} \\
\hline 554 & 40 & F & $42 \mathrm{Nn}$ & $64 \mathrm{Nn}$ & $63 \mathrm{Nn}$ & $\begin{array}{l}11 \mathrm{Nn} \\
32 \mathrm{Nn} \\
27 \mathrm{Nn}\end{array}$ & \multirow{5}{*}{$\begin{array}{l}36-\mathrm{n} \\
34-\mathrm{n} \\
50 \mathrm{Nn} \\
\\
34-\mathrm{n} \\
25-\mathrm{n}\end{array}$} & & \\
\hline 499 & 48 & $\mathbf{M}$ & $50 \mathrm{Nn}$ & $74 \mathrm{Nn}$ & $72 \mathrm{Nn}$ & $27 \mathrm{NH}$ & & & \\
\hline $\begin{array}{l}508 \\
273\end{array}$ & $\begin{array}{l}48 \\
29\end{array}$ & $\stackrel{M}{M}$ & $\begin{array}{l}46 \mathrm{Nn} \\
33 \mathrm{Nn}\end{array}$ & $64 \mathrm{Nn}$ & & $\begin{array}{l}38 \mathrm{Nn} \\
41 \mathrm{Nn}\end{array}$ & & \multirow[t]{3}{*}{$17 \mathrm{Nn}$} & \\
\hline 5 & 32 & $M$ & & & & & & & \\
\hline 381 & 23 & $M$ & & & $45 \mathrm{Nn}$ & $\begin{array}{l}24 \mathrm{Nn} \\
22 \mathrm{Nn}\end{array}$ & & & \\
\hline \multicolumn{10}{|c|}{ Three Sib Families } \\
\hline 34 & 43 & $\mathbf{M}$ & & \multirow{8}{*}{$69 \mathrm{Nn}$} & \multirow{8}{*}{$70 \mathrm{Nn}$} & $\begin{array}{l}53 \mathrm{Nn} \\
51 \mathrm{Nn}\end{array}$ & \multirow{8}{*}{$\begin{array}{l}65 \mathrm{Nn} \\
51 \mathrm{Nn} \\
41-\mathrm{a} \\
34-\mathrm{n} \\
47 \mathrm{An} \\
53 \mathrm{Nn} \\
45-\mathrm{n} \\
53 \mathrm{Nn} \\
32-\mathrm{n} \\
29-\mathrm{n} \\
42-\mathrm{n}\end{array}$} & \multirow{8}{*}{$21 \mathrm{Nn}$} & \multirow{8}{*}{$\begin{array}{l}22-n \\
16-n\end{array}$} \\
\hline 275 & 67 & $\mathbf{M}$ & $66 \mathrm{Nn}$ & & & $62 \mathrm{An}$ & & & \\
\hline 506 & 33 & $\mathbf{F}$ & $40 \mathrm{Nn}$ & & & $40 \mathrm{Nn}$ & & & \\
\hline 272 & 56 & $\mathbf{F}$ & $58 \mathrm{Nn}$ & & & $46 \mathrm{An}$ & & & \\
\hline 107 & 44 & F & $47 \mathrm{Nn}$ & & & $\begin{array}{l}39 \mathrm{Nn} \\
37 \mathrm{Nn}\end{array}$ & & & \\
\hline 555 & 49 & $\mathbf{F}$ & $49 \mathrm{Nn}$ & & & $\begin{array}{l}43 \mathrm{Nn} \\
49 \mathrm{Nn}\end{array}$ & & & \\
\hline 498 & 38 & $\mathbf{M}$ & $38 \mathrm{Nn}$ & & & $35 \mathrm{Nn}$ & & & \\
\hline 543 & 39 & $M$ & $33 \mathrm{Nn}$ & & & $\begin{array}{l}41 \mathrm{Nn} \\
37 \mathrm{Nn} \\
\end{array}$ & & & \\
\hline \multicolumn{10}{|c|}{ Four Sib Families } \\
\hline 418 & 58 & $\mathbf{M}$ & $61 \mathrm{Nn}$ & & & $\begin{array}{l}59 \mathrm{Aa} \\
55 \mathrm{Nn}\end{array}$ & & $30 \mathrm{Nn}$ & \\
\hline 303 & 54 & $\mathbf{M}$ & & & & $\begin{array}{l}59 \mathrm{Nn} \\
47 \mathrm{Nn} \\
\end{array}$ & $\begin{array}{l}43-\mathrm{n} \\
63 \mathrm{Nn} \\
\end{array}$ & & \\
\hline \multicolumn{10}{|c|}{ Five Sib Families } \\
\hline 269 & 26 & $\mathbf{M}$ & $26 \mathrm{Nn}$ & $53 \mathrm{Nn}$ & $52 \mathrm{Nn}$ & $\begin{array}{l}26 \mathrm{Nn} \\
24 \mathrm{Nn} \\
22-n\end{array}$ & $\begin{array}{l}33-n \\
27-n\end{array}$ & \multirow{5}{*}{$18 \mathrm{Nn}$} & \multirow{5}{*}{$\begin{array}{l}21-n \\
18-n \\
17-n\end{array}$} \\
\hline 138 & 46 & $M$ & $47 \mathrm{Nn}$ & $71 \mathrm{Nn}$ & $70 \mathrm{Nn}$ & $\begin{array}{l}32 \mathrm{Nn} \\
53-\mathrm{n}\end{array}$ & $\begin{array}{l}42-n \\
42-n \\
41-n\end{array}$ & & \\
\hline 155 & 48 & $\mathbf{M}$ & $41 \mathrm{Nn}$ & & $87 \mathrm{Nn}$ & $46 \mathrm{Nn}$ & $\begin{array}{l}61-1 \\
60 \mathrm{Nn} \\
58 \mathrm{An}\end{array}$ & & \\
\hline 357 & 55 & $\mathbf{M}$ & $54 \mathrm{Nn}$ & & & $\begin{array}{l}65 \mathrm{Nn} \\
50 \mathrm{Nn}\end{array}$ & $\begin{array}{l}52 \mathrm{Nn} \\
50 \mathrm{An} \\
70 \mathrm{Nn} \\
5 \mathrm{Tn}\end{array}$ & & \\
\hline 394 & 52 & $\mathbf{M}$ & $56 \mathrm{Nn}$ & & & $\begin{array}{l}55 \mathrm{Nn} \\
47 \mathrm{Nn}\end{array}$ & $\begin{array}{l}57 \mathrm{Nn} \\
56 \mathrm{Nn} \\
38-\mathrm{n}\end{array}$ & & \\
\hline \multicolumn{10}{|c|}{ Six Sib Families } \\
\hline 43 & 48 & $\mathbf{M}$ & & & & $\begin{array}{l}40 \mathrm{Nn} \\
55 \mathrm{Nn} \\
42 \mathrm{An}\end{array}$ & $\begin{array}{l}54 \mathrm{Nn} \\
49 \mathrm{Nn} \\
47 \mathrm{Nn}\end{array}$ & \multirow{4}{*}{$17 \mathrm{Nn}$} & \multirow{4}{*}{$22-n$} \\
\hline 3 & 45 & $\mathbf{M}$ & $33 \mathrm{Nn}$ & & & $\begin{array}{l}64 \mathrm{Nn} \\
58 \mathrm{Nn} \\
56 \mathrm{Nn} \\
52 \mathrm{Nn}\end{array}$ & $\begin{array}{l}50 \mathrm{Nn} \\
42-\mathrm{n}\end{array}$ & & \\
\hline & 52 & $\mathbf{M}$ & $51 \mathrm{Nn}$ & & & $\begin{array}{l}59 \mathrm{Nn} \\
54 \mathrm{Nn} \\
46 \mathrm{Nn}\end{array}$ & $\begin{array}{l}56 \mathrm{Nn} \\
48 \mathrm{Nn}\end{array}$ & & \\
\hline 571 & 37 & $M$ & $36 \mathrm{Nn}$ & & & $\begin{array}{l}39 \mathrm{Nn} \\
37 \mathrm{Nn} \\
36 \mathrm{Nn} \\
30 \mathrm{Nn}\end{array}$ & $\begin{array}{l}28-n \\
24-n\end{array}$ & & \\
\hline \multicolumn{10}{|c|}{ Seven Sib Families } \\
\hline 271 & 35 & $M$ & $36 \mathrm{Nn}$ & & & $\begin{array}{l}34 \mathrm{Nn} \\
39 \mathrm{Nn} \\
40 \mathrm{Nn} \\
41 \mathrm{Nn}\end{array}$ & $\begin{array}{l}41-n \\
39-n \\
29-n\end{array}$ & & \\
\hline
\end{tabular}

